J. Zool., Lond. (1973) 171, 189-206

\title{
The ear in Amphisbaenia (Reptilia); further anatomical observations
}

\author{
ERnest Glen Wever \\ Auditory Research Laboratories, Princeton University, Princeton, New Jersey \\ AND \\ Carl Gans \\ Department of Zoology, The University of Michigan, Ann Arbor, Michigan
}

(Accepted 8 May, 1973)

(With 4 plates and 7 figures in the text)

The anatomy of the ear, and especially of the sound-receptive and conductive system, was studied in nine species of amphisbaenians. In all species a region of skin is used as the sound-receptive surface, and the vibrations are transmitted along a columellar apparatus consisting of cartilage and bone that expands to form a footplate in the oval window of the cochlea. In all species but one the receptive skin area is on the face; in the form Bipes biporus it is in the region of the neck constriction.

The structures of the inner ear present a fairly uniform pattern, except for species variations of nearly four-fold in the size of the hair-cell population. The amphisbaenian extracolumella is shown to be an epihyal and not homologous to the structure of the same name in lizards.

\section{Contents}

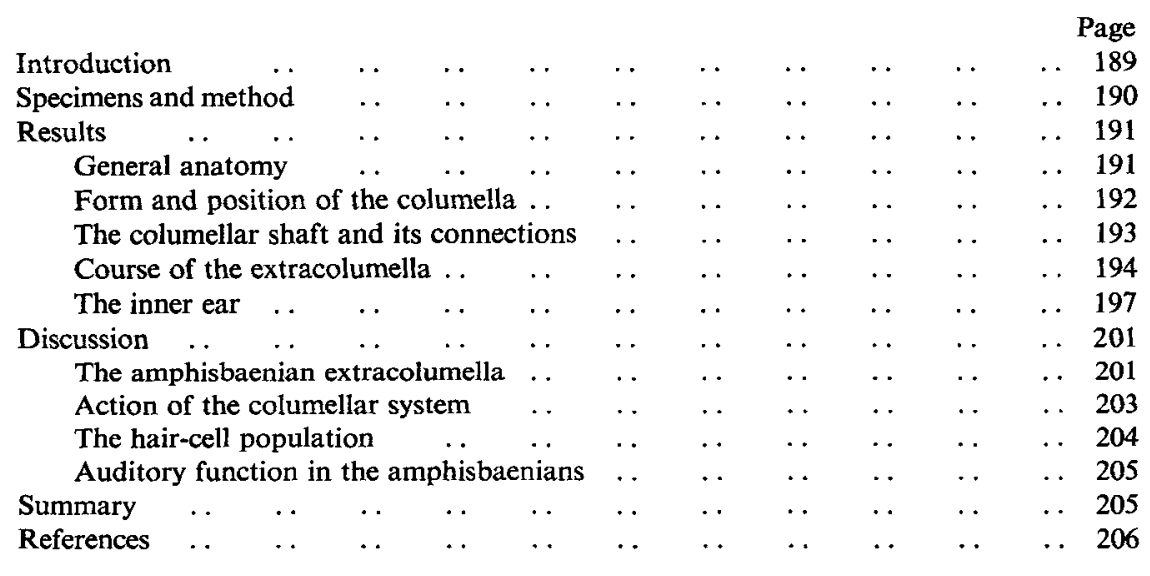

\section{Introduction}

Even the earliest students of the burrowing squamates of the order Amphisbaenia noticed that these lacked an external ear and had only a drastically reduced middle ear, so that the sound receiving system was quite aberrant. Stannius (1856), Peters (1882), Bedriaga (1884) and Smalian (1885) commented on the curious cartilages lateral to the 
jaw joint and variously homologized these to the jugal or the malleus. Versluys (1898), who provided a detailed analysis of the middle and outer ear region of Amphisbaena fuliginosa and Trogonophis wiegmanni, considered these elements to be extracollumellae, but argued that they no longer retained any function in sound perception. Fürbringer (1922), in a posthumous memoir, suggested that the homology was properly with the dorsal horn of the hyoid, a suggestion rejected by most subsequent authors.

Two previous reports have dealt with our studies on the structure and function of the amphisbaenian ear. The first of these gave results on nine species, showing auditory sensitivity in terms of the electrical potentials of the cochlea, together with observations on the distinctive type of sound-receptive mechanism in these animals. The form of this receptive mechanism was described in some detail for the genera Amphisbaena and Trogonophis, but was indicated only in a general way for the others for which the histological processing had not been completed (Gans \& Wever, 1972). The second report described the distinctive conductive mechanism of Bipes biporus, presented evidence that the amphisbaenian extracolumella was homologous with elements of the hyoid arch, and included further observations on the auditory sensitivity of this species (Wever \& Gans, 1972).

The histological preparations have now been completed for all specimens and we here present a general account of the amphisbaenian auditory apparatus, with comments on the functional and phylogenetic meaning of these structures.

\section{Specimens and method}

The species studied were Amphisbaena alba (3 specimens), Amphisbaena darwini trachura (1 specimen), Amphisbaena manni (7 specimens), Chirindia langi (2 specimens), Cynisca leucura (3 specimens), Zygaspis violacea (3 specimens), Monopeltis c. capensis (2 specimens), Trogonophis wiegmanni ( 2 specimens), and Bipes biporus ( 6 specimens). For data on provenance see Gans $\&$ Wever (1972).

The experimental procedure was as follows. The animals were anesthetized with ethyl carbamate (Urethane) of a special selected grade, in a dosage of $0.01 \mathrm{ml} / \mathrm{g}$ of body weight of a $20 \%$ solution in physiological saline. For the recording of cochlear potentials an active electrode consisting of a stainless steel needle, insulated except at the tip, was inserted into the cavity of the saccule on the left side, with two other electrodes (one of which was grounded) located in inactive tissues near by. The animal was stimulated with sounds from a loudspeaker conducted through a tube whose opening was placed (except for Bipes biporus) close over the skin of the face on the left side, but not touching, and the narrow gap filled with a ring of cotton wool soaked in petroleum jelly. This precaution in delivering the sound stimuli was taken to avoid a direct transmission of mechanical vibrations from the tube. In Bipes biporus the procedure was the same except that the tube was located laterally over the neck constriction where the end of the columella reaches the skin surface in this divergent species.

Pure tones were delivered to the ear at the sound pressures required to produce cochlear potentials of a standard value of $0.1 \mu \mathrm{V}$, or sometimes of a greater value when a relatively high noise level was encountered (as occasionally happened for the lowermost tones).

After completion of the cochlear potential measurements, the animal was perfused through the heart with a fixative containing mercuric chloride, potassium dichromate, sodium sulphate, and formaldehyde, and then a block of tissue containing both ears was removed. This block was exposed to further fixation by immersion and then decalcified in a solution of $0.5 \%$ nitric acid in $10 \%$ formol for 10-14 days, with daily changes of solution. Thereafter the tissue was dehydrated in ascending concentrations of ethyl alcohol, imbedded in celloidin, and finally 
sectioned at $20 \mu \mathrm{m}$ intervals, usually in a plane perpendicular to the longitudinal axis of the basilar membrane. In this orientation the nose is tipped downward about $20^{\circ}$ and the cutting is from dorsal and slightly posterior to ventral and slightly anterior. Every section through the ear region was mounted separately and stained with hematoxylin, azocarmine, and orange G. For further details the reader is referred to our earlier account (Gans \& Wever, 1972).

\section{Results \\ General anatomy}

Amphisbaenians lack an external ear and do not show any exterior indication of the ear's location; inner and middle ear divisions are present. Well-developed otic labyrinths occupy the posterior part of the skull, on either side of the brain. The vestibular portion of the labyrinth has a relatively large oval window, forming almost the whole lateral wall, in which lies the correspondingly large footplate of the columella.

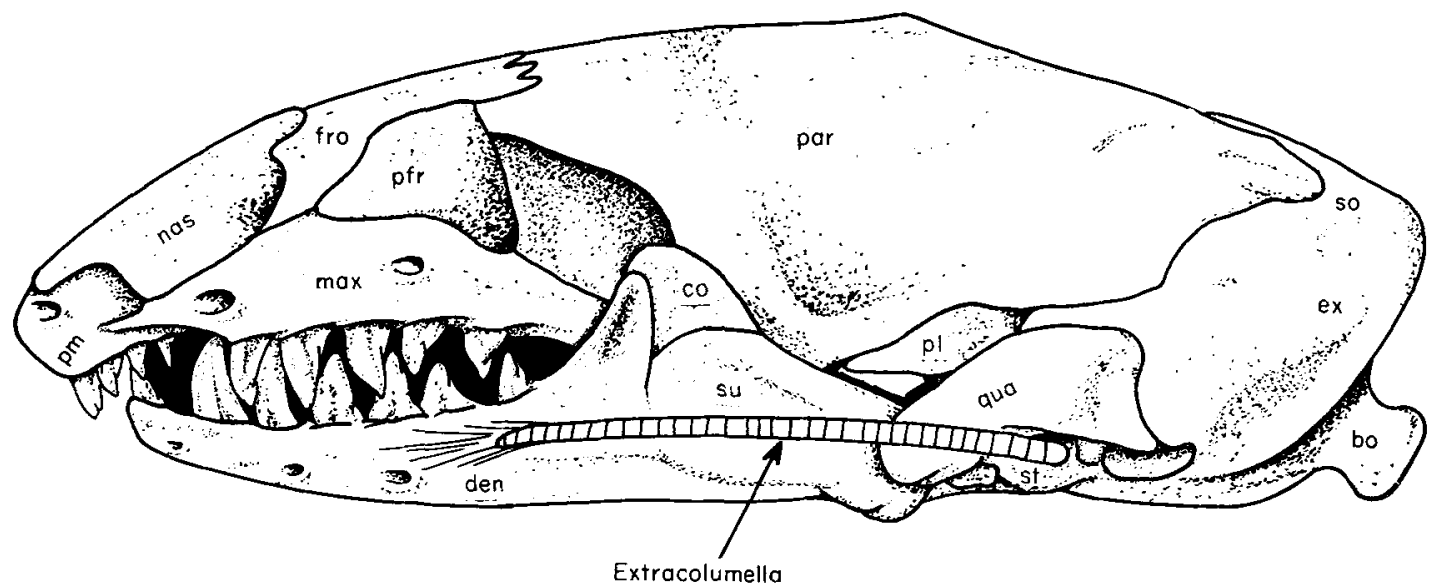

FIG. 1. A lateral view of the skull of Amphisbaena manni. The columella (stapes) lies in the oval window and the extracolumella is shown in its anterior course along the quadrate and mandible. bo, Basioccipital; co., coronoid; den, dentary; ex, exoccipital ; fro, frontal; max, maxilla; nas, nasal; par, parietal; pfr, prefrontal; pl, pleurosphenoid; pm, premaxilla; qua, quadrate; so, supraoccipital; st, stapes; su, surangular.

The conductive mechanism of the middle ear consists of a stout osseous columella (often, because of its shape, referred to as a stapes). All species examined except Bipes have an articulated, cartilaginous extracolumella which runs anteriorly to an area of skin that serves as the sound-receptive surface. This receptor site lies on some part of the face, and is distinguished by a local thickening of the dermal layer.

Figure 1 gives a lateral view of the head of Amphisbaena manni, with the conductive mechanism left in place. The oval window is seen somewhat obliquely because it faces ventrally and anteriorly as well as laterally. The shaft of the columella extends ventrolaterally and slightly anteriorly, but hardly projects beyond the surrounding rim of the window. Spaces or sinuses in the sheathing connective tissues permit the system to move slightly. These relations may be seen in further detail in Fig. 2, which is a ventrolateral view of the oval window region.

The head of the columella is covered by the slightly expanded end of the extracolumella. The ribbon of cartilage runs anteriorly, at first in a shallow groove in the surface of the 
quadrate, and then lateral to the mandible to end in a dermal thickening anterior to the angle of the mouth (Fig. 3).

This general picture holds fairly well for seven other amphisbaenian species studied (i.e., for all except Bipes). Variations in detail occur. These variations are seen in the form, size, and orientation of the columella, the type of junction with the extracolumella, the path taken by the extracolumella in its extension to the receptive skin surface, and the form of connection to this skin surface.

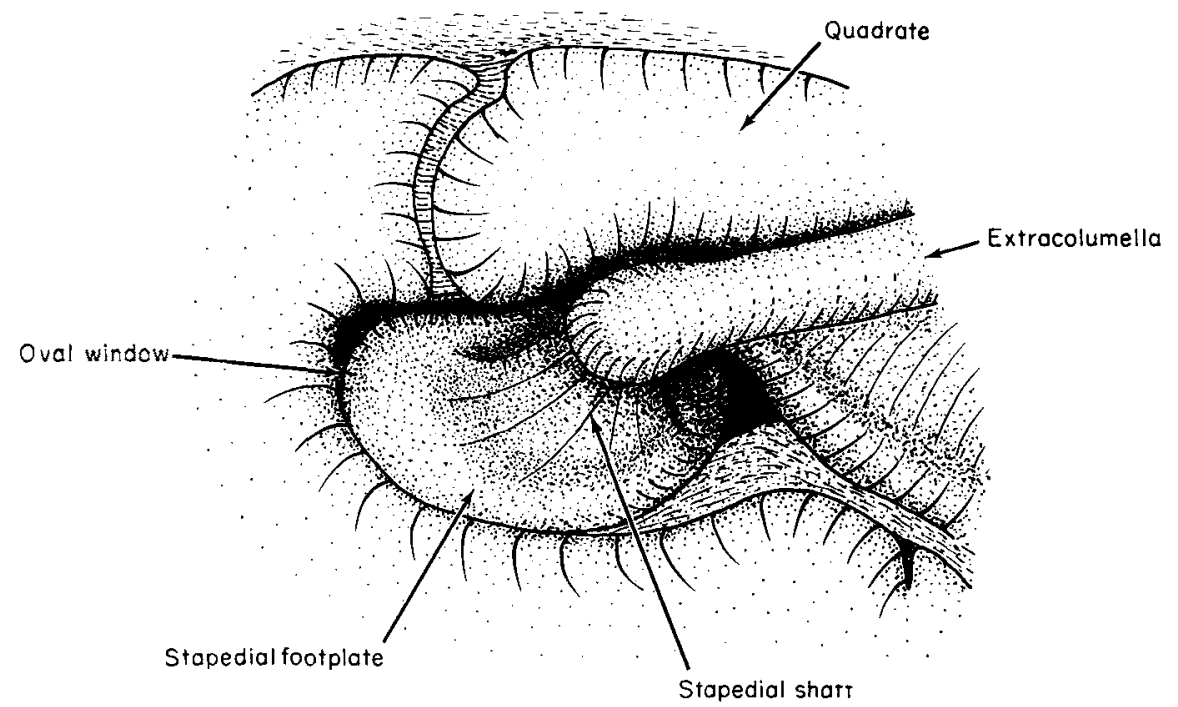

FIG. 2. Detail of the oval window and columella of $A$. manni. (Front faces right). Scale $\times 40$.

\section{Form and position of the columella}

The columella has already been shown in a general way for Amphisbaena manni in Figs 1 and 3. The form of this structure was studied in all the species by the use of serial sections, and some conception of the variations found may be obtained from the outline drawings of Fig. 4. These drawings represent the form of the structure as it appears in a section located about halfway along the series in which the footplate appears. Here the footplate is seen close to its largest dimensions (in this somewhat oblique view) and a little dorsal to the place at which it sends off its shaft portion. The views for the different species are thus roughly comparable.

The variations in relative size are perhaps the most striking feature, ranging from the relatively enormous footplate of Amphisbaena alba to the much smaller one of Chirindia langi. The forms are fairly similar among the three species of Amphisbaena, and this similarity extends also to Trogonophis and Monopeltis. The remaining three forms differ, as shown on the right of the figure.

There are variations also in the directions in which the footplates face, and for Chirindia langi, Zygaspis violacea, and Cynisca leucura the direction is noticeably more anterior than for the others.

Of particular interest is the wide anteromedial portion of the footplate, which closely articulates with the wall of the otic capsule, as may be seen in Fig. 3. In the species of 
Amphisbaena this articulation is noticeably curved; in the others the surface is more or less plane. The posterolateral portion of the footplate is relatively narrow, and its connection with the capsular wall is by a rather thick ligament.

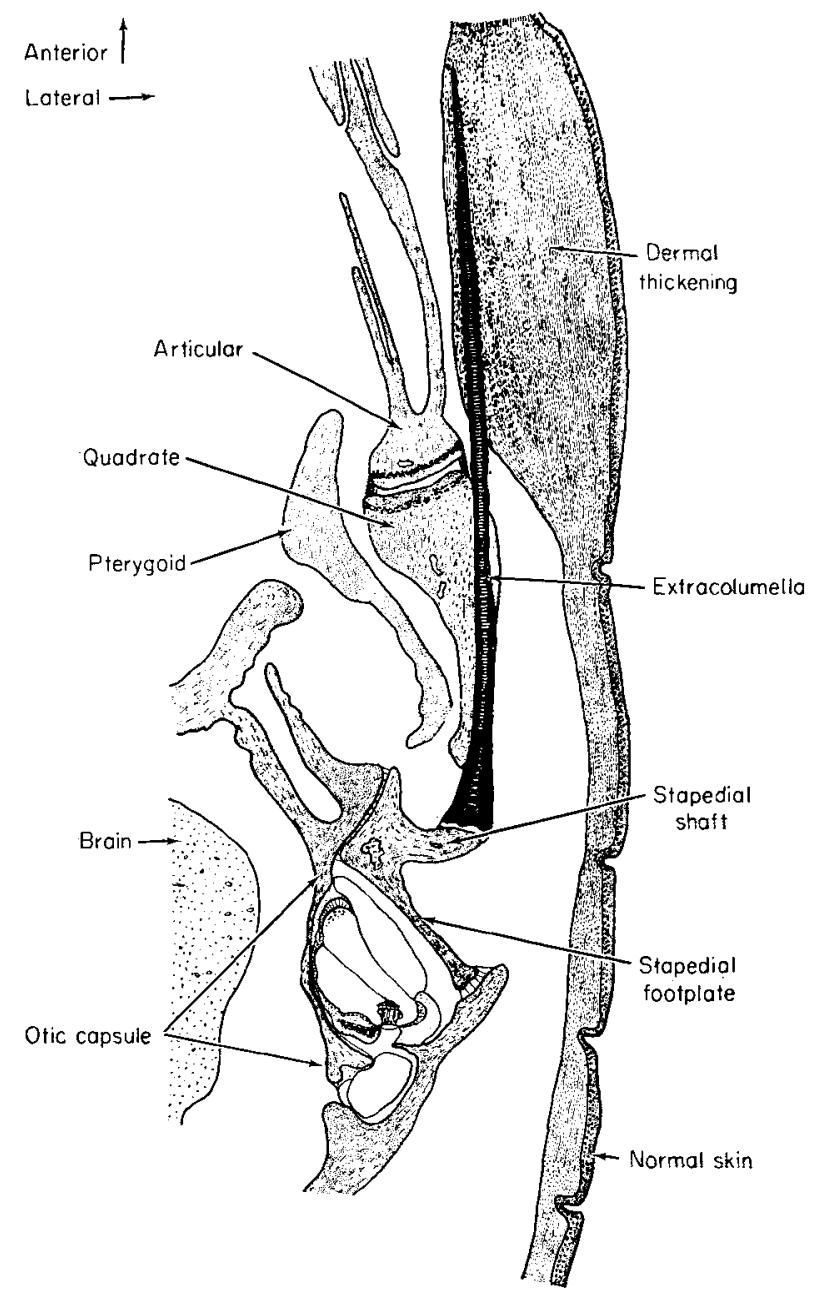

FIG. 3. Longitudinal (horizontal) view of the auditory system of $A$. manni. $\times 25$.

\section{The columellar shaft and its connections}

In Cynisca, Zygaspis, and Chirindia the shaft is longest (relatively). In Cynisca the length about equals the width of the footplate, in Zygaspis it is a little longer, and in Chirindia (as shown in Plate I) it is nearly twice as long as the width of the footplate. In all of these species the columella is continuous with the extracolumella. It may well be that the shaft is even more curved in other species, as Vanzolini (1951) illustrates its head within the posterior aspect of a groove formed respectively of the quadrate and the pterygoid flange (Cynisca leucura) or of the side of the quadrate(Chirindia orientalis). 
In Trogonophis the shaft is shorter, about equal in length to half the width of the columellar footplate. It extends anterolaterally and joins the extracolumella without physical discontinuity.

The short shaft already seen in Amphisbaena manni is characteristic of the other species of Amphisbaena as well. This shaft extends laterally and ventrally, and ends in a nearly flat surface for the attachment of the extracolumella. In these species there is a definite discontinuity at the union with the extracolumella, most marked in A. manni.

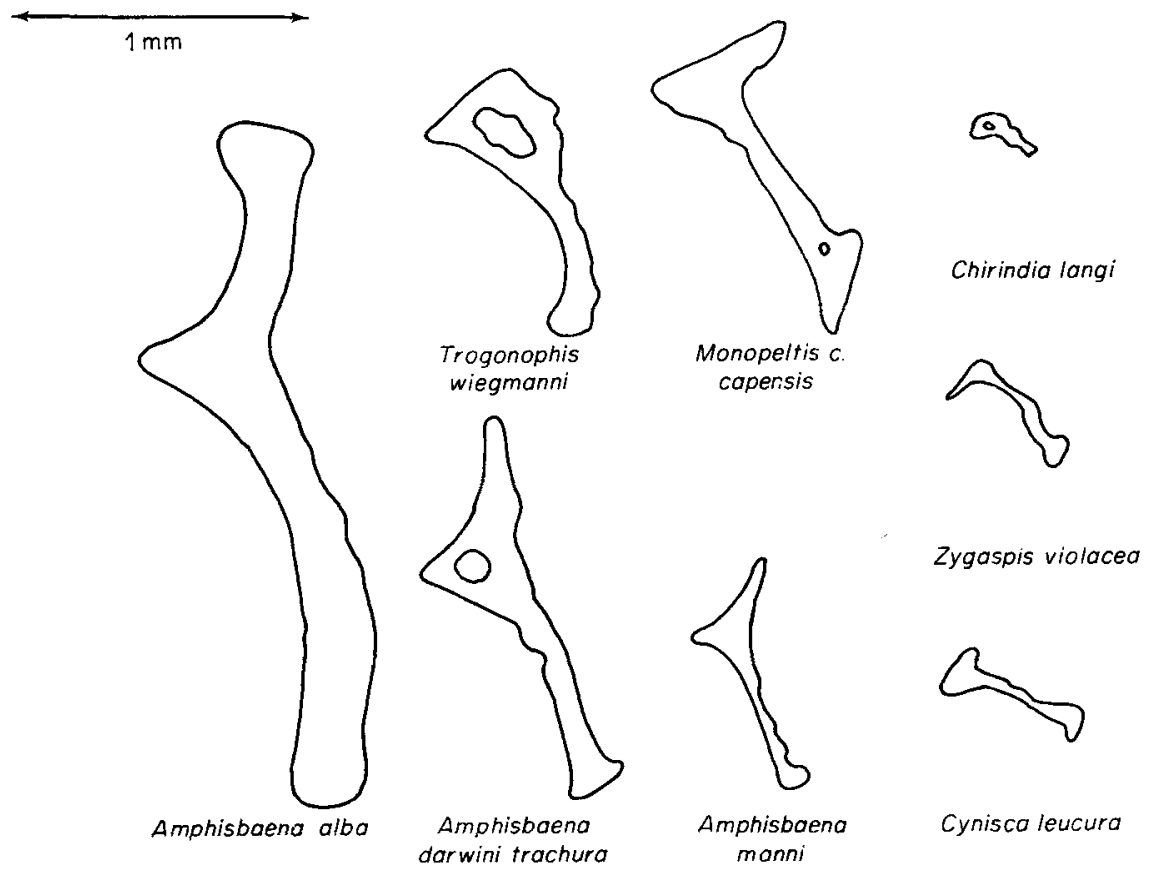

FIG. 4. Outlines of columellar footplates of eight species of amphisbaenians. Plane of section is obliquely longitudinal.

Monopeltis hardly has a columellar shaft. As shown in Plate II, the head portion of the columella arises from the middle of the footplate and forms a large mound-like surface for the articulation of the extracolumella. This joint is distinct, with well-formed articulatory surfaces, which is in contrast to Kritzinger's (1946) statement that stapes and extracolumella have fused.

The extracolumella is similarly short in Rhineura (Camp, 1923) in which it also contains a small ossification at the point of articulation (Baird, 1970).

Bipes lackes an extracolumella, and the columellar shaft terminates in a round button.

The same condition has been described for Blanus cinereus and B. strauchi (Bedriaga, 1884; Smalian, 1885).

\section{Course of the extracolumella}

In the three species of Amphisbaena and in Monopeltis the extracolumella arises at a fairly lateral position and runs almost directly anteriorly along the external surface of 


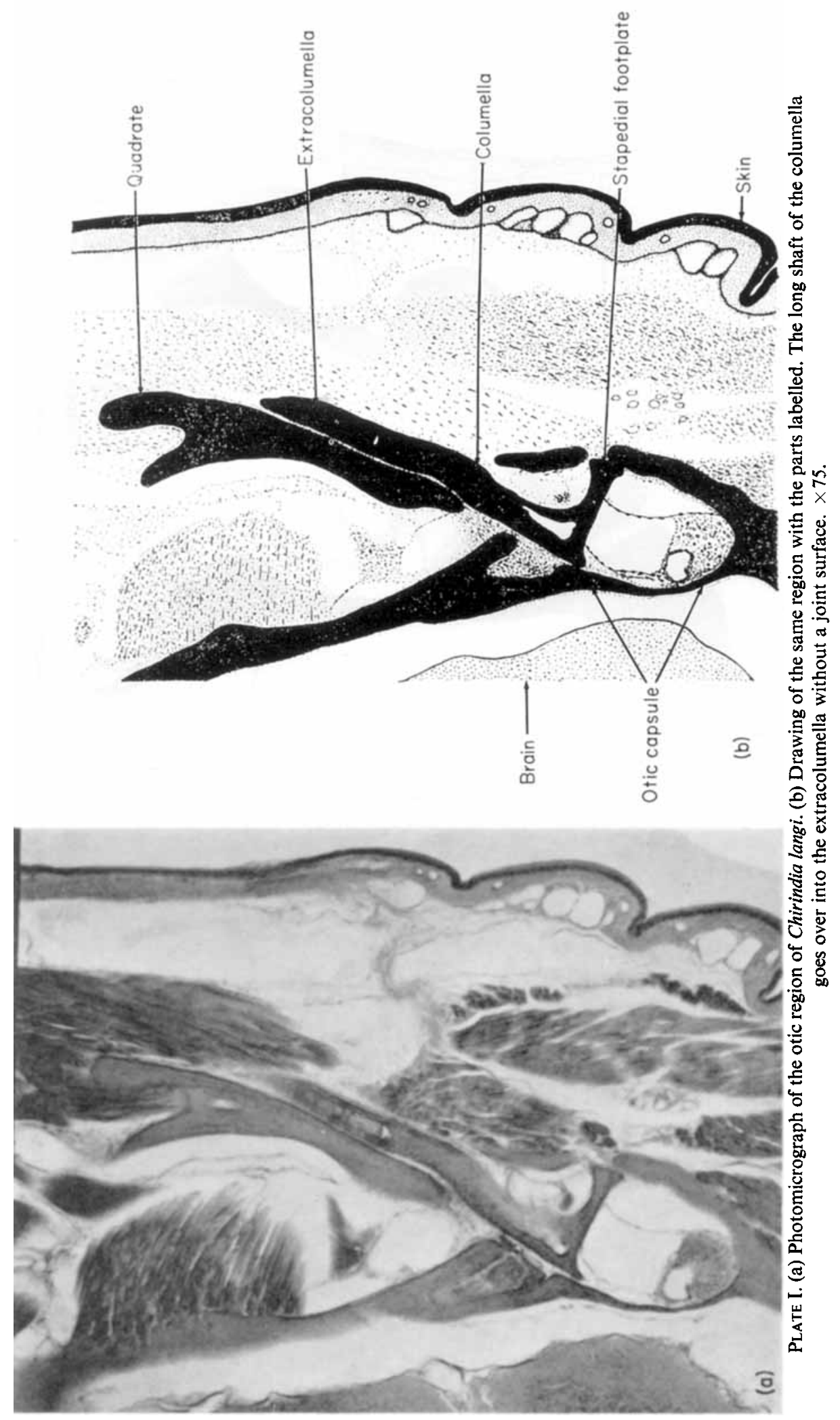




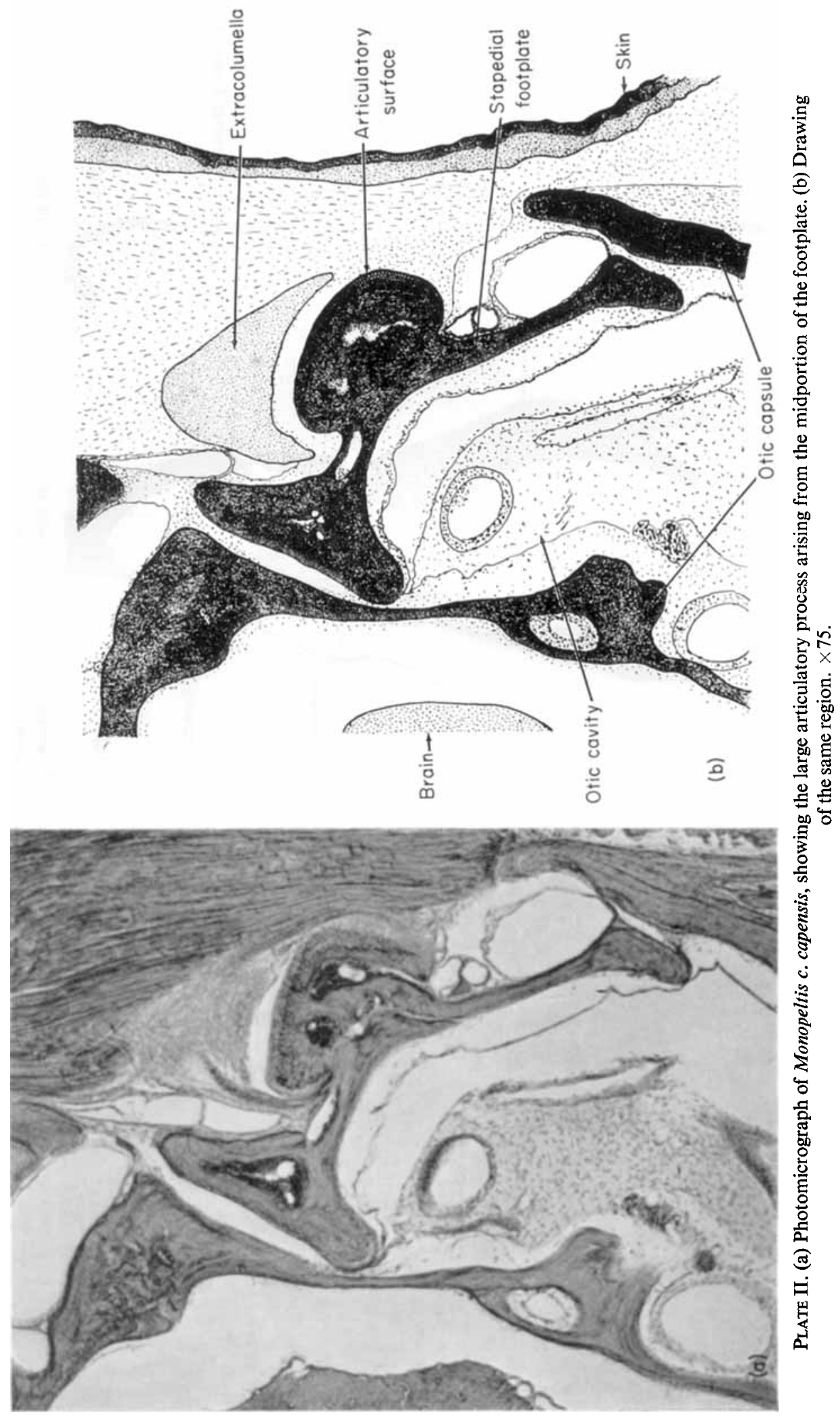


the quadrate. In the other species the course of the extracolumella is at first anterolateral, and then becomes more anterior beyond the quadrate.

In Trogonophis the anterior extension of the extracolumella is short and barely passes the articulation between quadrate and articular. Lateral to this it connects to a broad band of connective tissue that continues anterolaterally to join the dermal pad in the cheek region as shown in Plate III. Zygaspis shows a similar strand of connective tissue extending to the dermal pad. Its extracolumella does not terminate early as in Trogonophis, but continues to run anteriorly and to enter the dermal pad much as in other species.

In the advanced trogonophid amphisbaenians the extracolumella is entirely ossified. It forms a large triangular, bony plate lateral to the quadrate and has broad fibrous attachments to both upper and lower labials (Gans, 1960). Dissection of a specimen of Trogonophis wiegmanni (Mus. Comp. Zool., No. 1430) showed that a few of the connectve tissue strands passed to the upper jaw as well.

In Cynisca and Amphisbaena alba the extracolumella extends somewhat farther, but terminates well posterior to the most posterior tooth. In Chirindia it almost reaches this last tooth, in $A$. manni and $A$. darwini trachura it extends past this tooth. In Monopeltis it goes still farther, almost to the level of the next to last tooth.

In most of the species studied the extracolumella enters the dermal pad in the facial region and runs anteriorly just below its inner surface, as in Fig. 3 and Plate IV(a). It usually continues almost to the anterior end of this thickened region.

In Zygaspis and $A$. darwini trachura the extracolumellar cartilage runs a little deeper in the dermal pad, well below its inner surface, and in $A$. alba it is deeper still, near the middle of the pad's thickening (see Plate IV(b)).

\section{The inner ear}

The cochlear portion of the labyrinth is fairly uniform among the species studied. The general arrangement is shown in Fig. 5 for $A$. manni. The footplate of the columella fills the large oval window, which faces anterolaterally. On the basilar membrane, supported by the lateral and medial edges of the limbus, is the auditory papilla, shown here near its widest part with several transverse rows of hair cells. Over the ciliary tufts of these hair cells, and attached to their tips, is a tectorial plate from which runs a thin tectorial membrane to an anchorage on the medial wall of the cochlear duct. The scala tympani in its more ventral region makes a wide connection with the perilymphatic recess, as shown. This recess opens into the brain cavity in this region, separated from it only by the arachnoid membrance. At the place represented in the drawing the arachnoid is thickened about the glossopharyngeal nerve, which is passing through the posterior edge of the otic capsule.

The most striking variation among species was in the number of hair cells. In our earlier report we gave the results of hair cell counts on 13 specimens representing 5 amphisbaenian species. We have now extended this number to 23 specimens belonging to 9 species; as the observations usually included both ears there are 43 counts in all. The results are given in Table I. The observations for the different species are too few for reliable averages, but the means are given as they may indicate trends.

Clearly Amphisbaena alba stands by itself with the highest mean of 153.6 . Second, with means around 100 , is a group including $A$. manni, A. darwini trachura, and Trogonophis wiegmanni. Next in order, with numbers around 50, are Zygaspis violacea, Bipes 

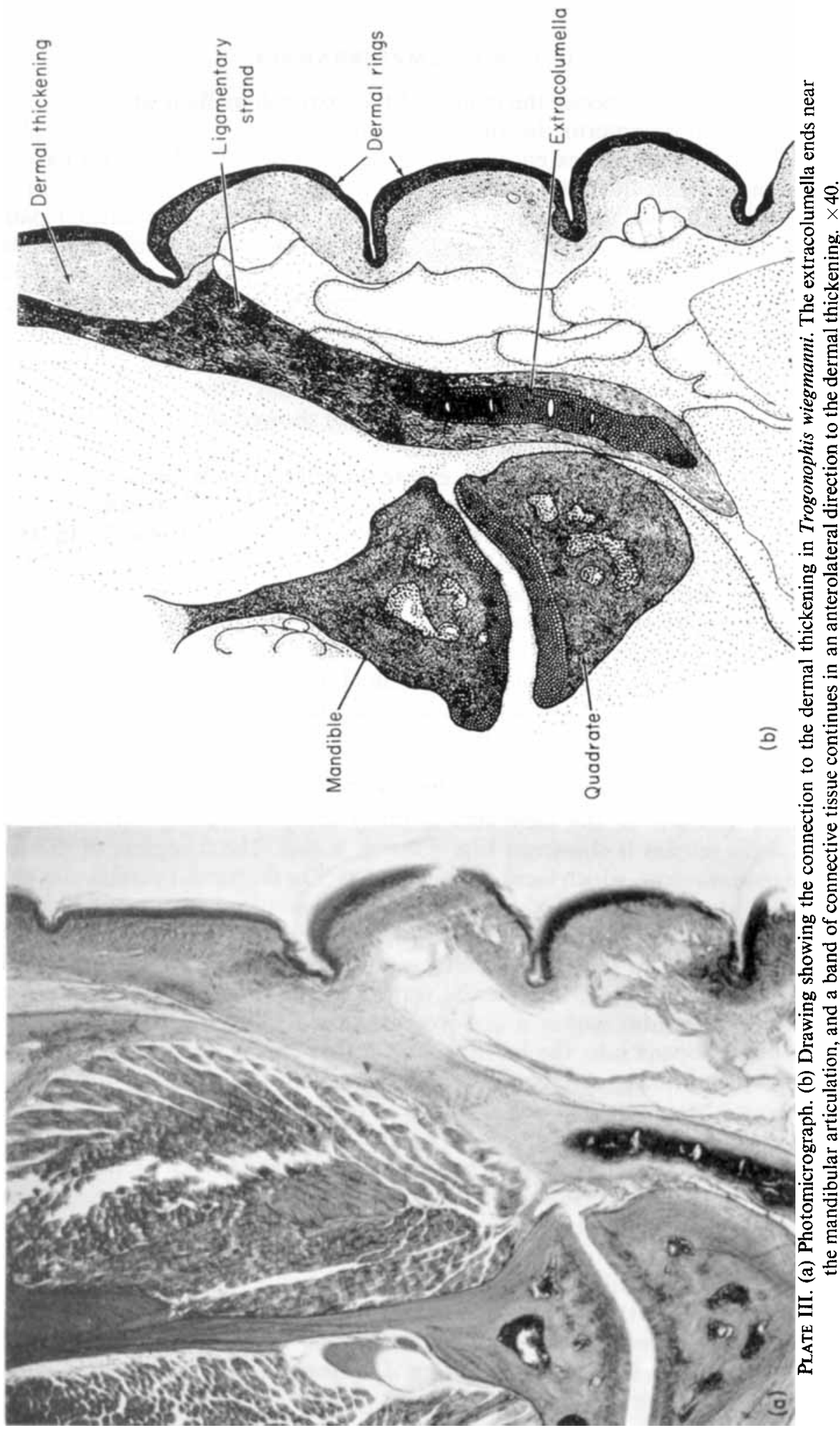

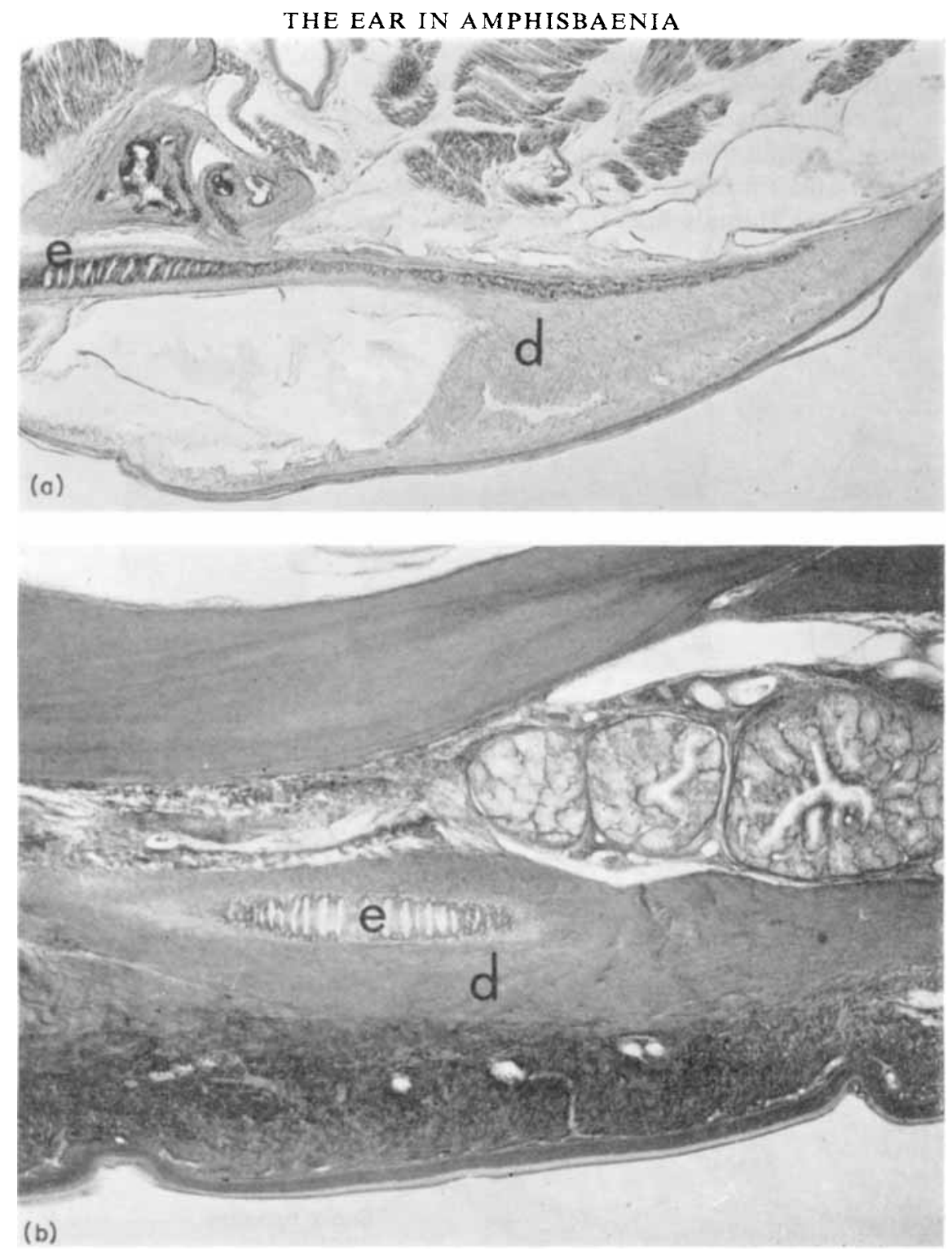

Plate IV. (a) Extracolumella (e) of Cynisca leucura and its embedment in the medial surface of the dermal pad (d). (b) the location of the extracolumella (e) of Amphisbaena alba in the interior of the dermal pad (d). $\times 40$.

biporus, and Cynisca leucura. Finally, with counts hardly reaching 40, are Chirindia langi and Monopeltis capensis.

It is interesting that the largest species has the highest mean, while the smallest is included in the lowest class.

The relations between hair-cell numbers and body weight are portrayed graphically in Fig. 6, where the points represent individual animals with the values averaged for right and left ears (with three exceptions in which only one ear was studied). A trend is 
evident, though strongly determined by the two extreme species, A. alba and Chirindia langi. The correlation (product-moments method) between body weight and hair-cell population was calculated as 0.65 for the individual animals represented in this figure. This correlation became 0.78 when determined from species averages.

When $A$. alba and Chirindia langi are omitted from this correlation, the value for the remaining individual animals falls to $\mathbf{0 \cdot 3}$. As the graph shows, there remain two clusters,

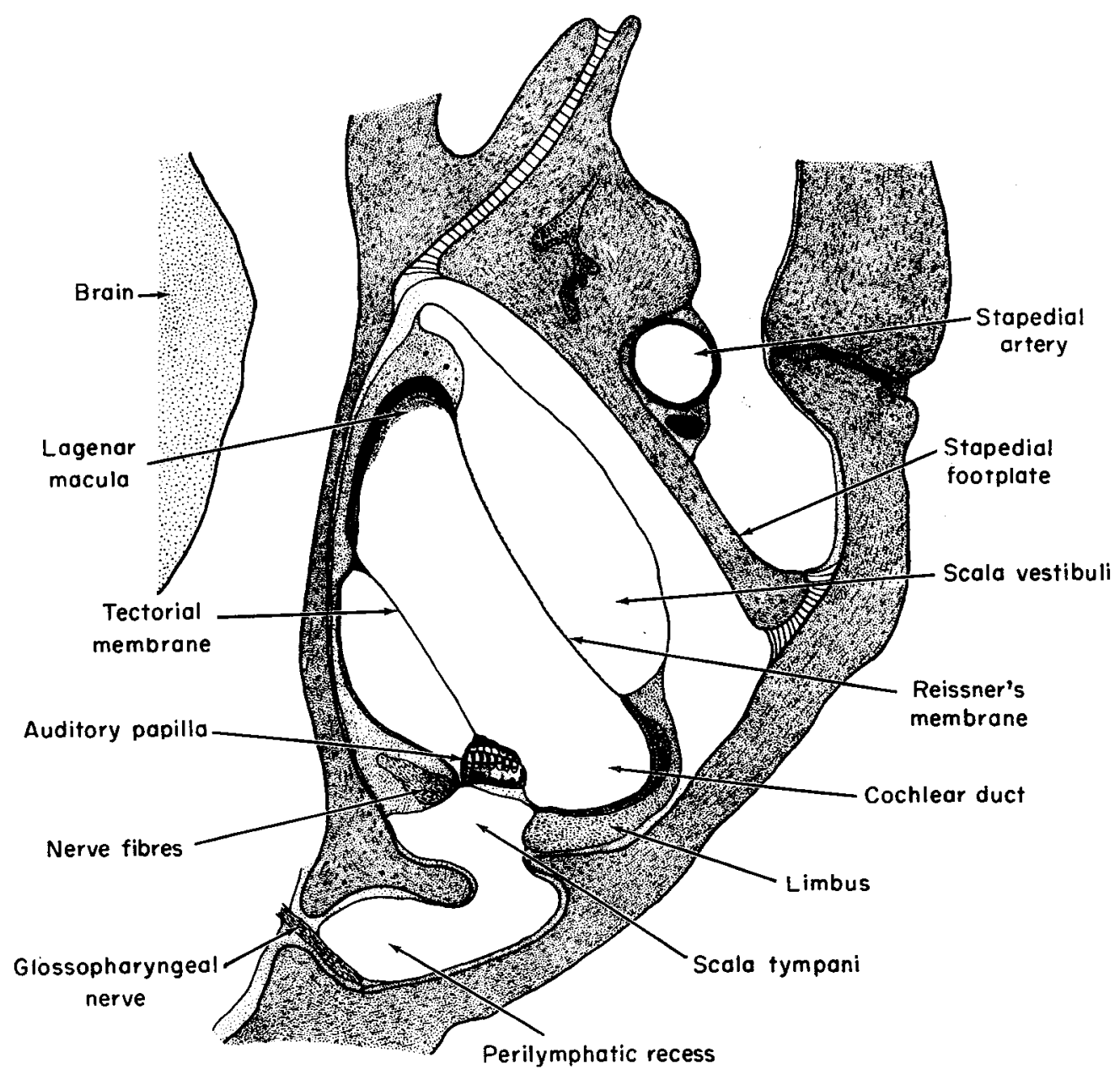

FIG. 5. A longitudinal section through the inner ear of A. manni. $\times 75$.

one containing $A$. manni, A. darwini trachura, and Trogonophis wiegmanni, and the other containing Cynisca leucura, Monopeltis c. capensis, Zygaspis violacea, and Bipes biporus; these clusters differ relatively little in body weight but differ considerably in hair cell numbers. It is evident that for these animals the size of the hair-cell population must have causes other than body size. There is no evidence here for ontogenetic increase in hair cell population. 
It is interesting that Trogonophis wiegmanni, otherwise quite generalized, shows the best frequency range and sensitivity. The cranially unspecialized Bipes biporus also shows above-average values, while all other species follow in a group (Gans \& Wever, 1972; Wever \& Gans, 1972).

TABLE I

Number of hair cells

\begin{tabular}{|c|c|c|c|c|}
\hline \multirow[b]{2}{*}{ Species } & \multicolumn{4}{|c|}{ Number of cells } \\
\hline & Animal number & Left ear & Right ear. & Means \\
\hline \multirow{4}{*}{ Amphisbaena alba } & 1500 & 150 & 148 & \\
\hline & 1667 & 159 & 168 & \\
\hline & 1668 & - & 143 & \\
\hline & & & $N=5 \quad \ldots$ & $153 \cdot 6$ \\
\hline \multirow[t]{2}{*}{ Amphisbaena darwini trachura } & 1525 & 99 & 105 & \\
\hline & & & $N=2 \quad \ldots$ & $102 \cdot 0$ \\
\hline \multirow[t]{7}{*}{ Amphisbaena manni } & 1519 & 108 & 115 & \\
\hline & 1520 & 71 & 109 & \\
\hline & 1523 & - & - & \\
\hline & 1524 & 107 & 138 & \\
\hline & 1547 & 99 & 78 & \\
\hline & 1548 & 105 & 101 & \\
\hline & & & $N=10 \ldots$ & $103 \cdot 2$ \\
\hline \multirow[t]{5}{*}{ Bipes biporus } & 1522 & 56 & - & \\
\hline & 1553 & 45 & 53 & \\
\hline & 1554 & 47 & 67 & \\
\hline & 1555 & 56 & 55 & \\
\hline & & & $N=7$ & $54 \cdot 1$ \\
\hline \multirow[t]{3}{*}{ Chirindia langi } & 1769 & 37 & 46 & \\
\hline & 1776 & 35 & 35 & \\
\hline & & & $N=4$ & $38 \cdot 2$ \\
\hline \multirow[t]{4}{*}{ Cynisca leucura } & 1772 & 45 & 46 & \\
\hline & 1773 & - & - & \\
\hline & 1774 & 52 & 57 & \\
\hline & & & $N=4$ & $50 \cdot 0$ \\
\hline \multirow[t]{3}{*}{ Monopeltis c. capensis } & 1767 & 36 & 39 & \\
\hline & 1768 & - & - & \\
\hline & & & $N=2$ & $37 \cdot 5$ \\
\hline \multirow[t]{3}{*}{ Trogonophis wiegmanni } & 1730 & 94 & 94 & \\
\hline & 1736 & 94 & 106 & \\
\hline & & & $N=4 \quad \ldots$ & $97 \cdot 0$ \\
\hline \multirow{4}{*}{ Zygaspis violacea } & 1770 & 48 & 50 & \\
\hline & 1771 & - & 74 & \\
\hline & 1775 & 56 & 51 & \\
\hline & & & $N=5$ & 55.8 \\
\hline
\end{tabular}

\section{Discussion}

The amphisbaenian extracolumella

The homologies of the amphisbaenian extracolumella have already been shown to be confused, in part because of lack of embryological data and also because of the reliance on antique dissections apparently made with inadequate optical equipment. Thus Cope 
(1892) described the hyoid of Bipes biporus as lacking the dorsal (cerato- and epihyal) processes of the hyoid; all our sections show them unequivocally.

Since an interpretation depends upon a correct analysis of the processes of the amphisbaenian hyoid apparatus, it seems appropriate briefly to review this. As indicated in Fig. 7 , the hyoid contains an azygous, anteriorly-projecting lingual process departing from a central body which may be the basihyal part of the hyal arch. Short (hypo- or ceratohyal) processes extend anteriorly and are generally homologized with the ventral portion of the hyoid arch (Fürbringer, 1922; Richter, 1933).

Two pairs of posterior processes ordinarily depart from the basihyal. A medial and cartilaginous pair lies immediately adjacent to the trachea and is interpreted as the second

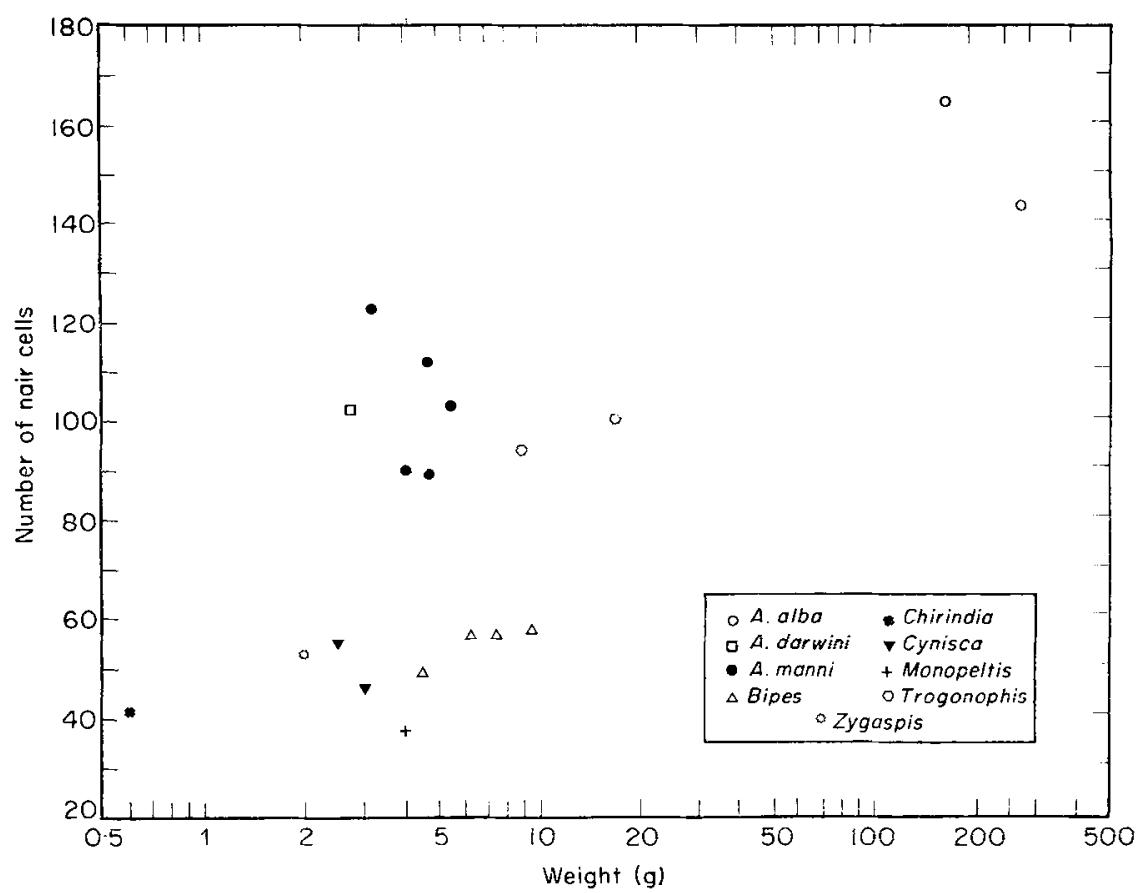

FIG. 6. Relation between body weight and size of the hair cell population in 19 individuals belonging to 9 species. Most of the points represent averages of right and left ears. The legend on the lower right identifies the species.

branchial arch. Further laterally are the horns of the first branchial arch often showing an ossified element (Gans, 1960).

In Bipes and apparently in some other forms (Camp, 1923; Gans, unpubl.; Richter, 1933) the hyoid body extends farther laterally and sends forth a third, thin and cartilaginous rod. In most forms this rod soon terminates, but in Bipes it swings ventromedially to the mandible and then rises to pass lateral to the quadrate and terminates freely in the vicinity of the otic region. This is clearly the position shown by Fürbringer (1922) for the dorsal hyoid arch in Sphenodon. In various lizards, such as some agamids, part of this dorsal limb of the hyoid is reduced to a strand of connective tissue which then attaches as a cartilaginous projection on the paroccipital process suggesting that this projection 
represents the remnant of a once continuous arch. In Calotes and Draco a ligament (M. stapedius) passes from the same process to the extracolumella (Versluys, 1898). These structures then are not directly derived from a primary dorsal horn of the hyoid arch.

Bipes biporus is unique (among the species examined) in lacking an extracolumella. The adults of this species are also unique in showing a continuous dorsal horn of the hyoid arch that passes to the occipital region (is this the epihyal or the ceratohyal?). This horn is missing or very short in all other amphisbaenians examined for this study. Under the circumstances it seems most plausible to argue that the cartilaginous rod in

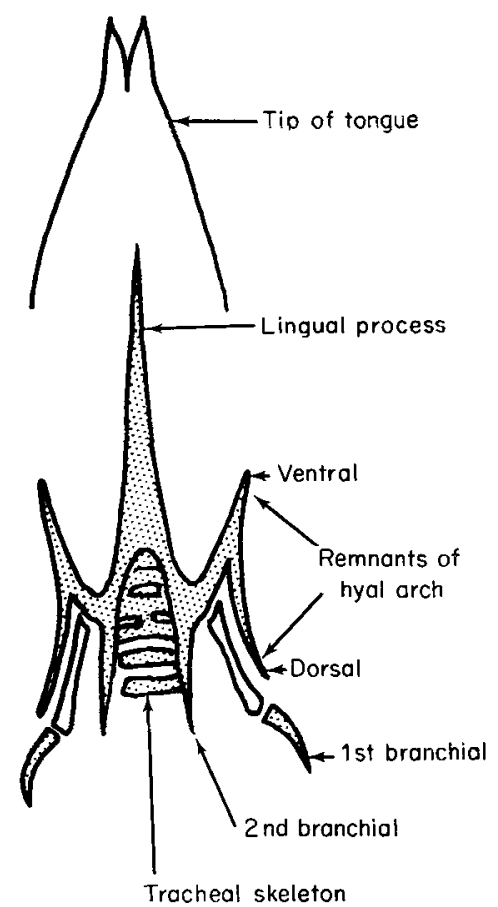

FIG. 7. The hyoid apparatus of Amphisbaena caeca, a species that retains a dorsal remnant of the hyoid arch. Stippled structures are cartilaginous; only the first ceratobranchial is ossified.

other amphisbaenians has changed attachment sites and to conclude that (1) the amphisbaenian extracolumella is really an epihyal, and since the lizard extracolumella does not directly derive from the hyoid arch, that (2) the amphisbaenian extracolumella is not homologous with the extracolumella of lizards. This finding seems to lend further support to the distinct status of Bipes among the Amphisbaenia and of the Amphisbaenia within the Squamata (Gans, 1969).

\section{Action of the columellar system}

The effectiveness in sound conduction of the chain of elements formed by the special skin area, extracolumella, and columella was demonstrated by the experiments in which this system was disrupted. Exposure of the extracolumellar cartilage had only a minor 
effect on sensitivity, but cutting the extracolumella gave reductions of sensitivity averaging 20 to $40 \mathrm{~dB}$ over the principal frequency range. Other experiments showed this ear to be directional in its response to aerial sounds. When potentials were recorded with two electrodes, one from each inner ear, the potentials were significantly larger in the ear close to an asymmetrically positioned sound source.

The arrangement of the columellar elements, and especially the form of the footplate and its relations to the otic capsule, suggest a particular form of motion in response to sound. The broad anteromedial edge of the footplate and its close apposition to the wall of the capsule (especially in the species of Amphisbaena in which the contact surface is curved) indicate a restriction of mobility, whereas the narrow and relatively loose connection on the posterolateral edge of the footplate indicates relative freedom from restraint. This arrangement suggests that the footplate is free to rotate about an axis in the region of its anteromedial edge.

It appears that when sound pressures are exerted on the dermal pad in the region of the face, this pad moves in and out, carrying the anterior end of the extracolumella with it. These movements of the extracolumella will be transmitted posteriorly along its length, probably in a complex manner because this rod is flexible and is under restraints both from tissue sheathings along its course and because for part of this course it runs in a shallow groove. The transmitted movements will probably be mainly anteroposterior, and when they reach the stapedial end of the system the restraint imposed by the anteromedial edge of the footplate converts them into rotations about an axis in that region. The swinging motions of the footplate displace the fluids of the cochlear duct, carrying the basilar membrane with them, and thereby bring about a stimulation of the sensory cells supported on this membrane.

\section{The hair-cell population}

The numbers of cochlear hair cells vary widely among the species studied. Though these numbers correlate positively with body size, this correlation is largely determined by the two species, Chirindia langi and Amphisbaena alba, that stand at the ends of the distribution. There are two intermediate clusters of forms nejther of which shows clear relation between body size and hair-cell population. Hence it appears that conditions other than body size must enter into the determination of the numbers of hair cells.

In general the size of the hair-cell population is a good indication of the level of development of an animal's hearing, and relates especially to the effectiveness of this sense in the discrimination of loudness and pitch. Among lizards, in which inter-species differences in hair-cell numbers are even greater than in the amphisbaenians, these numbers show a high correlation with the maximum potentials recorded from the cochlea. These observations have been taken to indicate differences in the intensity ranges that are covered by the different ears, and the discriminations of loudness that may be made within these ranges. Correspondingly it may be argued that those amphisbaenians with the greater numbers of hair cells, like Trogonophis and the three species of Amphisbaena, are advanced over the other species in the handling of information represented by the intensity dimensions of sound stimuli.

In animals in which the cochlea shows a considerable degree of physical differentiation along its length, most notably in the dimensions and stiffness characteristics of the basilar membrane and its related sensory structures, an increase in hair-cell numbers provides 
the possibility of selective response to different tonal frequencies. If there is a corresponding specificity of the nerve supply the ear acquires advanced capabilities of pitch discrimination. Such capabilities are demonstrable in the birds and mammals and probably are present in crocodilians and certain lizards in which the basilar membrance is elongate and markedly tapered along its course. In the amphisbaenians, however, as in snakes and turtles, there is little evidence of cochlear differentiation of this sort, and it seems unlikely that pitch discrimination is much advanced beyond the degree that can be afforded by a neural frequency representation of the periodicity of sounds.

The sensitivity of the ears of the different amphisbaenian species seems not to be closely related to hair-cell numbers just as was found to be true in lizards (Wever, 1965). It appears that the threshold sensitivity of an ear is determined by a very small number of hair cells favourably situated with respect to the stimulus.

\section{Auditory function in the amphisbaenians}

The biological values of hearing in the amphisbaenians provide an interesting subject for speculation. For animals that spend their lives in burrows underground, and for the most part in single isolation, the common function of hearing for the perception of alarm signals and as a means of communication seems to be excluded from serious consideration. There remains the possibility that hearing serves in the search for food, as discussed earlier by Gans (1960).

For a subterranian animal, vision and smell seem to be of little service as distance receptors. The sounds that worms and insects may produce when boring through the earth and breaking into the more or less permanent underground labyrinths that the amphisbaenians construct should give cues of their presence. Such sounds might be detected by vibrations transmitted through the earth if the amphisbaenian has its head in contact with a wall of its burrow. Such mass-conducted vibrations will probably lack directional qualities, however, and will only alert the animal to the presence of prey somewhere in its vicinity. Aerial sounds produced at the same time and conducted along the tunnels should be more precisely perceived and located. We have evidence, reported earlier, that the amphisbaenian ear responds to both aerial and surface conduction, and for aerial sounds the two ears operate so as to represent bilateral differences in a sound field.

The directional cues should be most serviceable in leading to the prey's capture. The indications therefore are that the hearing of amphisbaenians is one of their most important senses.

\section{Summary}

This comparative study reports on the anatomy of the ear, and especially of the sound receptive mechanism in nine species of amphisbaenians. In all of these the receptive surface is an area of skin that is relatively free to move in response to acoustic pressures, and that conveys the vibrations along a columellar apparatus to the oval window of the cochlea. In all the species studied except Bipes biporus the receptive skin area is on the face; in Bipes it is on a lateral portion of the neck constriction.

The conclusion is reached that the amphisbaenian extracolumella is a development from the epihyal process of the hyoid complex, and is not homologous with the 
extracolumella of lizards. In Bipes biporus (in which the epihyal persists), the extracolumella is lacking, and the columella makes a direct connection to the receptive skin area.

The inner ear structures in these nine species are relatively uniform, except for large variations in the size of the hair-cell population. It is presumed that these variations are relevant to the capabilities of these animals in dealing with the intensity dimension of sounds, and that those ears with the larger numbers of hair cells have a wide dynamic range and enhanced loudness discrimination.

Consideration is given to the problem of the usefulness of the auditory sense in the lives of these animals, and it is suggested that auditory cues are of assistance to them in locating prey.

The experiments were carried out in the Auditory Research Laboratories of Princeton University with facilities provided by grants from the National Institute of Neurological Diseases and Stroke. The specimens were obtained with funds from NSF GB-31088X which also supported travel. We thank R. G. Northcutt for comments on the manuscript.

\section{REFERENCES}

Baird, I. L. (1970). The anatomy of the reptilian ear. In Biology of the Reptilia 2: 193-375. Gans, C. and Parsons, T. S. (Eds.). London: Academic Press.

Bedriaga, J. V. (1884). Amphisbaena cinerea Vand. und A. Strauchi v. Bedr. Erster Beitrag zur Kenntniss der Doppelschleichen. Arch. Naturgesch. $50: 23-77$.

Camp, C. L. (1923). Classification of the lizards. Bull. Am. Mus. nat. Hist. 48:289-481.

Cope, E. D. (1892). The osteology of the Lacertilia. Proc. Am. phil. Soc. 30 (138): 185-221.

Fürbringer, M. (1922). Das Zungenbein der Wirbelthiere insbesondere der Reptilien und Vögel. Abh. heidelb. Akad. Wiss. (Math. Nat. KI.) 11 : xii +164.

Gans, C. (1960). Studies on amphisbaenids (Amphisbaenia, Reptilia). I. A taxonomic revision of the Trogonophinae, and a functional interpretation of the amphisbaenid adaptive pattern. Bull. Am. Mus. nat. Hist. 119: 135-200.

Gans, C. (1969). Amphisbaenians-reptiles specialized for a burrowing existence. Endeavour 28(105): 146-151.

Gans, C. \& Wever, E. G. (1972). The ear and hearing in Amphisbaenia (Reptilia). J. exp. Zool. 179: 17-34.

Kritzinger, C. C. (1946). The cranial anatomy and kinesis of the South African amphisbaenid Monopeltis capensis Smith. S. Afr. J. Sci. 42: 175-204.

Peters, W. C. H. (1882). Über eine neue Art und Gattung der Amphisbaenoiden, Agamodon anguliceps, mit eingewachsenen Zähnen, aus Barava (Ostafrica) und über die zu den Trogonophides gehörigen Gattungen. $A b h$. K. preuss. Akad. Wiss. 1892: 579-584.

Richter, H. (1933). Das Zungenbein und seine Muskulatur bei den Lacertilia vera. Jena. Z. Naturw. 66 [N.S. 59]: $395-460$.

Smalian, C. (1885). Beiträge zur Anatomie der Amphisbaeniden. Z. wiss. Zool. 92: 126-202.

Stannius, H. (1856). Die Amphibien. In Handbuch der Zootomie 2: 1-270. Zweite Auflage. Die Wirbelthiere. von Siebold, Ph.-F., and Stannius, H. (Eds.). Berlin.

Vanzolini, P. E. (1951). A systematic arrangement of the family Amphisbaenidae (Sauria). Herpetologica 7: 113123.

Versluys, J. Jr. (1898). Die mittlere und äussere Ohrsphäre der Lacertilia und Rhynchocephalia. Zool. Jb. (Anat.) 12: 161-406.

Wever, E. G. (1965). Structure and function of the lizard ear. J. Auditory Res. 5: 331-371.

Wever, E. G. \& Gans, C. (1972). The ear and hearing in Bipes biporus (Amphisbaenia: Reptilia). Proc. natn. Acad. Sci. USA 69: 2714-2716. 